\title{
Net Energy Balance and Fuel Quality of an Alley Cropping System Combining Grassland and Willow: Results of the 2nd Rotation
}

\author{
Ilze Dzene *, Frank Hensgen (D), Rüdiger Graß and Michael Wachendorf $(D)$
}

check for

updates

Citation: Dzene, I.; Hensgen, F.; Graß, R.; Wachendorf, M. Net Energy Balance and Fuel Quality of an Alley Cropping System Combining Grassland and Willow: Results of the 2nd Rotation. Agronomy 2021, 11 , 1272. https://doi.org/10.3390/ agronomy 11071272

Academic Editor:

Małgorzata Szczepanek

Received: 27 May 2021

Accepted: 20 June 2021

Published: 22 June 2021

Publisher's Note: MDPI stays neutral with regard to jurisdictional claims in published maps and institutional affiliations.

Copyright: (c) 2021 by the authors. Licensee MDPI, Basel, Switzerland. This article is an open access article distributed under the terms and conditions of the Creative Commons Attribution (CC BY) license (https:/ / creativecommons.org/licenses/by/ $4.0 /)$.
Grassland Science and Renewable Plant Resources, Faculty of Organic Agricultural Science, Universität Kassel, Steinstraße 19, 37213 Witzenhausen, Germany; gnr@uni-kassel.de (F.H.); rgrass@uni-kassel.de (R.G.); mwach@uni-kassel.de (M.W.)

* Correspondence: ilze.dzene@uni-kassel.de; Tel.: +49-5542-98-1245

Abstract: With the central aim to reduce greenhouse gas emissions, agroforestry systems have become popular because they can provide biomass for bioenergy conversion and thus help replace fossil energy. This article compares the net energy balances of three biomass conversion techniques for an agroforestry system consisting of willows and two types of grassland biomass as well as separate stands of grassland and willow. The period of investigation was the second willow rotation (4-6 years after establishment). The biomass conversion techniques included combustion of hay $(\mathrm{CH})$, integrated generation of solid fuel and biogas from biomass (IFBB), and anaerobic whole crop digestion (WCD). Compared to the first rotation (years 1-3), the net energy yield of the willow stands significantly increased. Nevertheless, the separate stand of willow had higher net energy yield than the agroforestry system. The IFBB technique led to an improvement in solid fuel quality through demineralization. $\mathrm{CH}$ and IFBB provided higher net energy yields than WCD.

Keywords: alley cropping; biofuels; energy balance; grassland; willow

\section{Introduction}

With the central aim to protect the climate system for the benefit of future generations, 197 parties ratified the United Nations Framework Convention on Climate Change [1]. In 2015, the Paris Agreement stated the convention parties' aim to keep the increase in global temperatures to "well below $2{ }^{\circ} \mathrm{C}$ above pre-industrial levels and to pursue efforts to limit the temperature increase to $1.5^{\circ} \mathrm{C}$ above pre-industrial levels" [2]. To reach this aim, a path to achieving net zero $\mathrm{CO}_{2}$ emissions is necessary [3]. Large-scale use of bioenergy combined with carbon capture and storage technologies could help by replacing fossil energy sources [4]. However, there have been discussions on the drawbacks of increasing and intensifying biomass production for energy conversion, such as biodiversity losses [5], nitrate leaching [6], soil erosion [7] and competition with food and forage production [8]. Thus, bioenergy systems should be improved in terms of their holistic sustainability [9]. While discussions are still ongoing regarding the criteria for measuring the sustainability of bioenergy conversion systems, the energy balance is considered a crucial criteria by most experts [9].

In several countries worldwide, implementation of short rotation coppice (SRC) on arable fields for bioenergy production has been discussed [10,11], especially driven by the high potential biomass and energy yields that such systems can achieve [12-14] and the low negative environmental impacts compared to other conversion systems (e.g., biogas production from annual crops) [15,16]. Dauber et al. [17] found SRC systems had higher biodiversity compared to arable food and energy crops such as maize, lower biodiversity compared to woodland habitats, and results were ambiguous compared to grassland. Mixed cropping systems, such as agroforestry systems including both short rotation wood 
biomass and arable crops or grassland, are an interesting alternative that could enhance diversity at the field and landscape scale and increase yield stability compared to singlecropped systems [18]. The multi-functionality of agroforestry enables provision of a variety of products and ecosystem services such as food, fodder and biomass production as well as erosion control, nutrient conservation and carbon sequestration $[19,20]$. Alley cropping has been developed as a type of agroforestry system which is adapted to a high degree of mechanization [21]. Trees and crops or grassland are planted or seeded in alternating rows, which facilitates their management by machinery and enhances productivity, whilst still providing various ecosystem services [22]. Moreover, agroforestry systems can help to overcome some limitations and decreasing profitability of pure SRC plantations. For example, a rapid decline of biomass yields over years, a high water demand, dependency on woodchip market prices and high costs of re-planting or converting the SRC stand back to the arable land.

The present study continues investigation of an alley cropping system consisting of grassland and fast-growing willows established in Germany in 2011 and described in detail by Ehret et al. and Graß et al. [23-25]. Both the grassland and willow biomass were intended to be used for bioenergy provision.

Combustion is the most used energy conversion technology for the woody biomass obtained from the SRC. The preferred form of the fuel is wood chips. Wood chips allow high degree of automation of the combustion process, at the same time, compared to wood pellets, require less energy for fuel production (chipping, milling, drying, and compacting operations). Fast growing tree species like Salix spp. and Populus spp. are especially well adapted to the temperate climate and thereby have good potential as agroforestry bioenergy carriers [26]. Due to small diameter of willow SRC stems and shoots, willow fuels have a relatively high bark content. With increasing bark content, the ash content of wood fuels increases. Although wood chips from willow SRC have higher ash content compared to forestry wood-based fuels, the heating values are only slightly lower than those of fir and pine wood fuels. Compared to other energy crops (e.g., poplar, miscanthus) and crop residues (e.g., cereal straw) willow SRC has better heating values and lower ash contents. Therefore, willow SRC wood offers a good alternative to forestry wood fuels used for heat production [27].

Biomass from grasslands with a high cutting frequency (3-4 cuts per year) was intended to be used for biogas production by anaerobic whole crop digestion (WCD). Biomass from grasslands cut 1-2 times a year was intended for combustion in form of hay $(\mathrm{CH})$. The major limitation for the use of grassland biomass in combustion systems is the higher maintenance costs due to more frequent slagging and corrosion risks, which are mainly related to high alkali and chlorine content in the biomass [28]. The system of integrated generation of solid fuel and biogas from biomass (IFBB, [29]) was developed to cope with these problems. The main element of this conversion procedure is mechanical dehydration after hydrothermal conditioning of ensiled biomass, which produces a solid fibrous fraction for thermal use (press cake) and a liquid fraction with easily fermentable constituents for biogas production (press fluid). The press fluid is used to produce biogas, which is converted by a combined heat and power plant into electricity and heat; the latter is used to dry the press cake. The fuel quality of the mechanically dehydrated whole crop silage is improved in comparison to the untreated biomass because of the partial elution of organic and mineral compounds which are detrimental to combustion [30,31].

Ehret et al. [23] investigated the bioenergy provision of combustion, IFBB and WCD within the first three-year rotation of the agroforestry systems, willow SRC reference, and grassland reference under consideration in the present study. Net energy yields for the SRC reference system and the agroforestry systems were lower than for the grassland reference system due to the low willow biomass yield in the establishment phase. In terms of energy conversion, direct combustion of hay or willows showed higher net energy yields than IFBB or WCD. However, the study only investigated the system for the first three years after establishment. Agroforestry systems evolve during their lifetime and a complete 
analysis should include more than the result from the first rotation [32]. Therefore, this paper evaluated the second rotation of the same system in comparison to the results of the first rotation with the objectives to (a) evaluate the energetic potential of three different conversion technologies applied to grassland biomass within the agroforestry system (i.e., $\mathrm{CH}$, IFBB, and WCD); (b) assess the energetic potential of the combustion of willow wood chips (CW); and (c) compare the net energy balance of grassland stands, willow stands, and agroforestry systems.

\section{Materials and Methods}

\subsection{Description of the Site and the Agronomic Systems}

The study was conducted at the field trial area of the Strengthening Bioenergy Regions (BEST) research project and the successor project Sustainable Intensification of Agriculture through Agroforestry (SIGNAL) in Lower Saxony, Germany $\left(51^{\circ} 24^{\prime} 2.466^{\prime \prime}\right.$ $\mathrm{N}$ and $\left.9^{\circ} 59^{\prime} 20.179^{\prime \prime} \mathrm{E}\right)$. The research within the BEST project was carried out from March 2011 to January 2014, including three years of grassland harvest, and was reported by Ehret et al. [23]. Between the two projects was a gap from January 2014 until June 2015. For this period, only yield data from grassland and willow SRC were available; there was no further analysis of the biomass. The research within the SIGNAL project was carried out between June 2015 and January 2018, including data on the second harvest of willow and second grassland cut in 2015 through the end of the 2017 season.

The climate at the experimental site is characterized by an average temperature of $9.2^{\circ} \mathrm{C}$ and an annual precipitation of $642 \mathrm{~mm}$. Within-site heterogeneity of soils is high with soil types ranging from Eutric Cambisols to Eutric Stagnic Cambisols [20] and stagnosol [33], consisting of sedimentary deposits from sandstone, siltstone and claystone [34].

Following winter barley harvest, three cropping systems were established in March 2011: (a) a grassland reference, (b) a willow SRC reference, and (c) an agroforestry system combining grassland and willow SRC [25]. The agroforestry system consisted of four alternating rows of willow SRC and three rows of grassland in the alleyways [25]. The total area of the alley cropping system was $0.7 \mathrm{ha}$, with $45 \%$ covered by willows and $55 \%$ by grassland. The width of grassland alleyways was $9 \mathrm{~m}$, and the length was $80 \mathrm{~m}$. Willows were planted in 7.5-m wide and 80-m long rows (Figure 1).

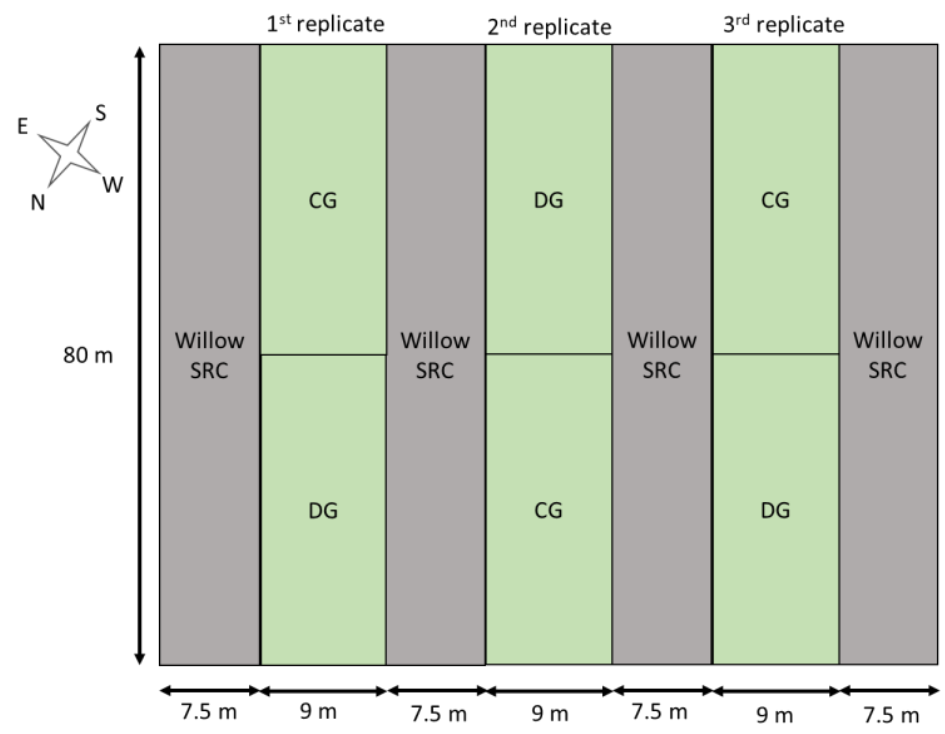

Figure 1. Alley cropping design of agroforestry system with different grassland types (CG = clover grass; DG = diverse grassland mixture) and willow stripes as short-rotation coppice (SRC), 3 replicates in grassland alleyways between the willow stripes. Reference plots of grassland and willow SRC were located at adjacent areas. 


\subsection{Experimental Design and Cultivation Measures}

As explained in [25], within the grassland reference plots and the grassland alleyways of the agroforestry system, two grassland mixtures were sowed: (a) a mixture of Lolium perenne L. and Trifolium repens L. (clover-grass, CG) with a clover proportion of 31\%; and (b) a diverse grassland mixture (DG) with 32 species, consisting of $43 \%$ grasses and $41 \%$ non-leguminous forbs. CG and DG plots were split into sub-plots of $9 \mathrm{~m}$ by $6.5 \mathrm{~m}$ size to consider different cutting regimes, including (a) two cuts per year (extensive use) and (b) three or four cuts per year (intensive management). The different nitrogen fertilization trials reported by Ehret et al. [23] were not continued in the second rotation. No nitrogen fertilization was applied during the second rotation. Unfortunately, reference grassland plots were destroyed by boars at the beginning of the 2nd rotation and were not usable for further analysis. Therefore, an adjacent grassland area with a local specific sward was used as reference grassland area for both grassland mixtures. However, this allowed a comparison with the yields of agroforestry system without a common statistical analysis only, as these plots were not part of the randomized factorial layout of the agroforestry design.

Willow SRC within the reference plot and the agroforestry system were hand planted. Dormant stem cuttings with 3-4 buds of the willow clone 'Tordis' ((Salix schwerinii $\times$ S. viminalis) $\times$ S. vim.) were used. SRC was planted in double rows. A planting density of 12,000 trees per ha was applied, with alternating inter-row distances of 0.75 and $1.5 \mathrm{~m}$, and with a within-row spacing of $0.75 \mathrm{~m}$. During the establishment phase, no herbicides or fertilizers were applied. In the first two years, manual weeding was performed with hoes and lawn mowers. A detailed overview of the field operations, including soil preparation, sowing/planting, maintenance and harvest, is given in Tables 1 and 2.

Table 1. Field operation data applied to grassland biomass to prepare it for combustion of hay $(\mathrm{CH})$, integrated generation of solid fuel and biogas from biomass (IFBB) and whole crop digestion (WCD). A farm to field distance of $5 \mathrm{~km}$ and a field size of 4 ha was assumed. Data are mean values for all agroforestry and grassland treatments accumulated over three years (second rotation) [35].

\begin{tabular}{|c|c|c|c|}
\hline \multirow{2}{*}{ Machinery } & \multicolumn{3}{|c|}{ Average Diesel Consumption ( $\left.\mathrm{L} \mathrm{ha}^{-1}\right)$} \\
\hline & WCD & IFBB & $\mathrm{CH}$ \\
\hline Cultivator and harrow, $2.5 \mathrm{~m}, 83 \mathrm{~kW}^{1}$ & $4.9^{1}$ & $4.9^{1}$ & $4.9^{1}$ \\
\hline Grass seed drill, $2.5 \mathrm{~m}, 83 \mathrm{~kW}{ }^{1}$ & $2.2^{1}$ & $2.2^{1}$ & $2.2^{1}$ \\
\hline Field roller, $6 \mathrm{~m}, 83 \mathrm{~kW}{ }^{1}$ & $0.7^{1}$ & $0.7^{1}$ & $0.7^{1}$ \\
\hline Mulcher, 3 m, 83 kW ${ }^{1}$ & $5.0^{1}$ & $5.0^{1}$ & $5.0^{1}$ \\
\hline Pasture harrow, $9 \mathrm{~m}, 83 \mathrm{~kW}$ & 1.8 & 1.8 & 1.8 \\
\hline Mower and conditioner $3.2 \mathrm{~m}, 83 \mathrm{~kW}$ & 44.6 & 29.4 & 28.4 \\
\hline Rotary tedder/turner, $8.75 \mathrm{~m}, 83 \mathrm{~kW}$ & - & - & 50.4 \\
\hline Rotary windrower & 28.5 & 18.0 & 18.0 \\
\hline Self-loading trailer, $28 \mathrm{~m}^{3}, 7 \mathrm{t}, 83 \mathrm{~kW}$ & 48.7 & 34.7 & \\
\hline Ensiling, wheel loader, $13.5 \mathrm{t}, 105 \mathrm{~kW}, 4 \mathrm{~m}^{3}$ & 7.4 & 5.7 & \\
\hline Round baler, $1.5 \mathrm{~m}, 320 \mathrm{~kg} / \mathrm{bale}, 67 \mathrm{~kW}$ & & & 16.9 \\
\hline Bale transport, front loader, dumper, $2 \times 8 \mathrm{t}, 1800 \mathrm{daN}, 54 \mathrm{~kW}$ & & & 9.0 \\
\hline Total & 147.4 & 105.9 & 141.8 \\
\hline
\end{tabular}

${ }^{1}$ Field operations that occur only once in the expected lifespan of the agroforestry system (18 years). Therefore, the total value for the whole lifespan was divided by the expected number of rotations (6).

\subsection{Assessment of Aboveground Biomass}

Aboveground biomass of the grassland was measured in the 2011-2017 growing seasons for both the reference grassland plots and the alleyways of the agroforestry system. At each harvest date, five randomized $0.25-\mathrm{m}^{2}$ subplots were sampled. Grass was cut at $50 \mathrm{~mm}$ stubble height, and the fresh mass was recorded. For determination of herbage dry matter (DM) content, 100 to $200 \mathrm{~g}$ of biomass from each sub-plot were dried at $105^{\circ} \mathrm{C}$ for $48 \mathrm{~h}$ and weighed.

Aboveground biomass of the willows in the reference plot and rows of the agroforestry system was harvested in February 2015 and February 2018. Fresh biomass was 
weighed, and samples of the shredded fresh biomass were dried at $105^{\circ} \mathrm{C}$ for $48 \mathrm{~h}$ for DM content determination.

Table 2. Field operation data for cultivation and harvest of willow SRC in an agroforestry system accumulated over a 3 year period (second rotation). A farm to field distance of $5 \mathrm{~km}$ and a field size of 4 ha was assumed [35].

\begin{tabular}{cc}
\hline Machinery & Average Diesel Consumption (L ha ${ }^{-\mathbf{1})}$ \\
\hline Cultivator and harrow, $2.5 \mathrm{~m}, 83 \mathrm{~kW}^{1}$ & $4.9^{1}$ \\
Planting, double row, $3 \mathrm{~m}, 102 \mathrm{~kW}$ & $2.0^{1}$ \\
Hoeing machine, $9 \mathrm{~m}, 67 \mathrm{~kW}^{1}$ & $0.9^{1}$ \\
Field Chopper, $9 \mathrm{~m}, 67 \mathrm{~kW}$ & 32.5 \\
Woodchip transport, $2 \times 10 \mathrm{t}, 67 \mathrm{~kW}$ & 22.0 \\
Forest rotary tiller, $160 \mathrm{~kW}^{1,2}$ & $4.2^{1,2}$ \\
\hline Total & 66.5
\end{tabular}

${ }^{1}$ Field operations that occur only once in the expected lifespan of SRC (18 years). Therefore, the total value was divided by the expected number of rotations (6). ${ }^{2}$ Ehret et al. [23].

\subsection{Conversion Technologies}

Three energy conversion technologies were compared: (a) $\mathrm{CH}$ and (b) IFBB were applied to the biomass from the extensive (two-cut) system, whereas biomass from the intensive (three- to four-cut) system was used for (c) WCD. Energy conversion tests were conducted with mixed biomass samples obtained from three replicates of each treatment at each harvesting date.

The general framework of the studied conversion technologies for grassland and willow SRC biomass described by Ehret et al. [23] was maintained in this study in order to allow comparison of results from the first rotation to the second. System definition including assessed energy conversion scenarios is illustrated in Figure 2. Machinery data used to calculate the energy balances are given in Tables 1 and 2.

Investigated systems

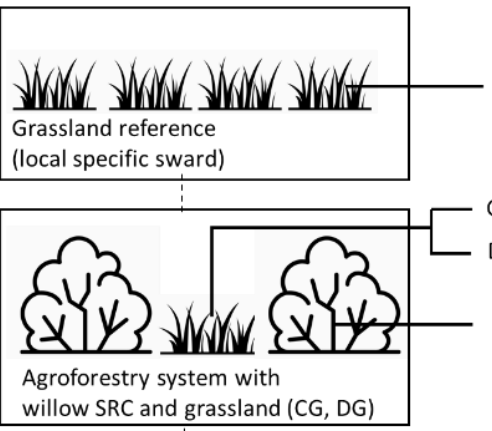

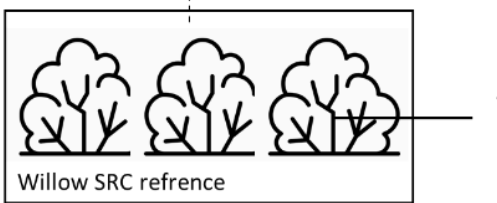

Diesel
Biomass

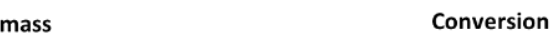

Outputs

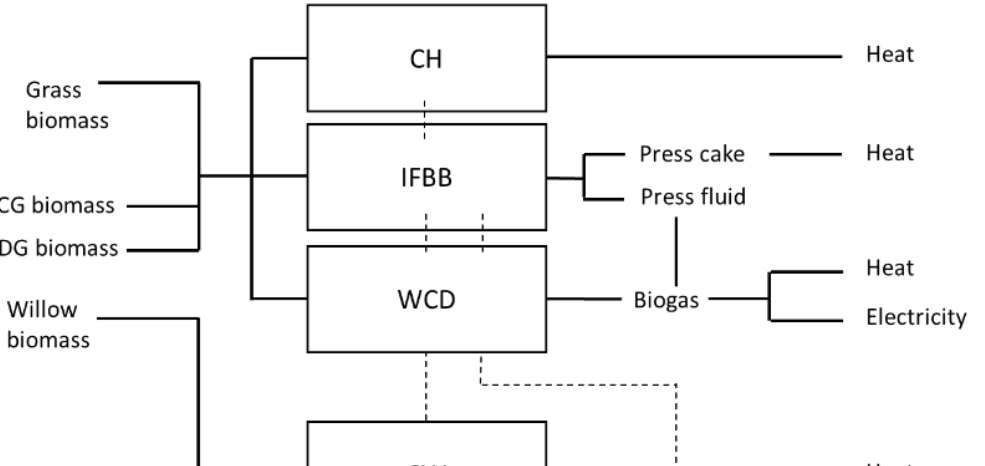

Willow biomass

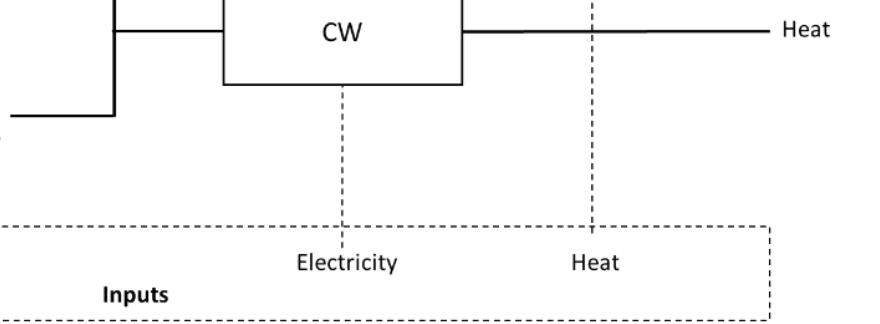

Inputs

Figure 2. General framework of investigated systems, biomass sources (CG = clover grass; DG = diverse grassland mixture, $\mathrm{SRC}=$ short rotation coppice $)$ and energy conversion pathways $(\mathrm{CH}=$ combustion of hay, $\mathrm{IFBB}=$ integrated generation of solid fuel and biogas from biomass, WCD = anaerobic whole crop digestion, $\mathrm{CW}=$ combustion of willow woodchips). 


\subsubsection{Combustion of Hay $(\mathrm{CH})$}

Grassland biomass was cut with a finger-bar mower at a stubble height of $50 \mathrm{~mm}$. Dried biomass samples were further investigated for combustion-relevant components such as ash, C, H, N, Ca, Cl, K, Mg, Na, P and S. Based on this information, calorific values of each biomass sample were calculated as described further in Section 2.5.

\subsubsection{Integrated Generation of Solid Fuel and Biogas from Biomass (IFBB)}

For IFBB treatments, the grassland biomass was harvested with a finger-bar mower at a stubble height of $50 \mathrm{~mm}$, windrowed, and wilted for two hours in the field. About $20 \mathrm{~kg}$ of the biomass was chopped to a length of $50 \mathrm{~mm}$, compacted, and ensiled in 60- $\mathrm{L}$ polyethylene barrels. Ensiling was done without any additives and lasted at least 3 months. During the IFBB processing, the silage was mixed with water at a ratio of 1:4 and heated up to $40{ }^{\circ} \mathrm{C}$ for $15 \mathrm{~min}$. A conical screw press was then used to separate a solid press cake for combustion and a liquid press fluid for anaerobic digestion. Thus, the press cakes were analyzed for combustion relevant parameters, and the press fluids for methane yields. Methodology for digestion of the press fluids is described in the following chapter.

\subsubsection{Whole Crop Digestion (WCD)}

WCD is a commonly applied system to convert wet plant biomass into biogas and finally into electricity and heat. It is particularly suitable for organic substrates with a high proportion of easily digestible compounds, including biomass from intensively-managed grasslands. Biomass conservation for WCD experiments followed the same method as for IFBB. Anaerobic digestion of silage and IFBB press fluids was conducted in batch experiments. Digestion experiments were conducted following the experimental set-up of Zerr [36], taking the German standard [37] into account. Frozen substrates (silage and press fluid) were thawed for $60 \mathrm{~h}$ at room temperature $\left(20^{\circ} \mathrm{C}\right)$. Substrates were fermented in 20-L polyethylene containers. For the silage digestion experiments, the containers were filled with $8 \mathrm{~kg}$ fresh matter of a digestate inoculum obtained from a nearby biogas plant, $3.6 \mathrm{~kg}$ of water and $400 \mathrm{~g}$ of whole crop grass silage. Silage was chopped by hand to approximately $5 \mathrm{~cm}$ in length and then mixed with inoculum and water. For digestion of press fluids, $4 \mathrm{~kg}$ of press fluid were mixed with $8 \mathrm{~kg}$ of inoculum. Digestion of silage took place in two replicates for 35 days, digestion of press fluids in three replicates for 14 days using gas-proof polyethylene containers at mesophilic temperature $\left(37 \pm 1{ }^{\circ} \mathrm{C}\right)$ and 15 min stirring every hour. Pure inoculum was digested separately to subtract the methane yield of the inoculum from the total amount of methane produced in mixtures and thereby calculate the actual yield from the sample.

Biogas was collected in gas-proof bags and volume was measured with a wet drum gas meter (TG5, Ritter, Bochum, Germany) at digestion days 1, 2, 3, 4, 7, 9, 11 and 14 for press fluids and additionally on days 16, 18, 21, 24, 28, 31 and 35 for silages. After these periods the daily biogas production was below $1 \%$ of total biogas production at this time. Methane concentration in biogas was measured with a gas analyser (GS IRM100, GS Messtechnik GmbH, Ratingen, Germany), standardised to normalised conditions (273.15 K, $101.325 \mathrm{kPa}$ ) and referred to volatile solids [28]. Volatile solids were determined as mass loss by drying a sub-sample at $105^{\circ} \mathrm{C}$ in a drying oven and subsequent incineration in a muffle furnace at $550{ }^{\circ} \mathrm{C}$. As parts of the volatile solids are lost during drying due to high volatility, the total amount of volatile solids in silage was corrected applying the following equation [38]:

$$
\mathrm{VS}_{\text {corrected }}[\%]=2.08+0.975 \times \operatorname{VS}_{\text {uncorrected }}[\%]
$$

where VS is the amount of volatile solids.

To correct the amount of volatile solids in press fluid, we assumed that the fraction of highly volatile substances calculated as above from the corresponding silages has the same mass flow as water into the press fluid because most of them are highly water soluble (e.g., short fatty acids, alcohols). 


\subsubsection{Combustion of Willow Wood Chips (CW)}

Cultivation machinery data used for calculation of energy balance of willow SRC are given in Table 2. Fuel characteristics of willow wood chips (e.g., higher heating value, ash and mineral concentrations) in this study was based on data and calculations from literature [39].

\subsection{Chemical Biomass Analyses}

Representative samples of 200 to $300 \mathrm{~g}$ from each grassland treatment and the IFBB press cakes were oven-dried at $65{ }^{\circ} \mathrm{C}$ for $48 \mathrm{~h}$ and ground with a FOSS sample mill (CyclotecTM 1093, Hahn, Germany) to pass through a $1 \mathrm{~mm}$ screen. Samples were analyzed for $\mathrm{C}, \mathrm{H}$, and $\mathrm{N}$ using an elemental analyzer (Vario MAX CHN Elementar Analysesysteme $\mathrm{GmbH}$, Hanau, Germany). X-ray fluorescence was used to determine the contents of $\mathrm{K}, \mathrm{Na}$, $\mathrm{Mg}, \mathrm{Ca}, \mathrm{Cl}, \mathrm{S}$, and $\mathrm{P}$. The lower- and higher-heating values (HHV) of hay and press cakes were calculated from the concentrations of $\mathrm{C}, \mathrm{H}$, and $\mathrm{N}$ with the empirical equation for biofuels from [40]. Lower heating values were used for calculations of net energy balances.

\subsection{Energy Balance}

Assessment of the energy balance for the agroforestry system was carried out as described by [23] in order to allow comparison of results. The net energy yield per ha was calculated as the difference between energy input and output. This calculation was applied for all cropping systems and treatments. Furthermore, the net energy yield of the agroforestry system was compared to the net energy yield of the grassland reference and pure willow SRC reference stands.

The functional unit was normalized to 1 ha for the grassland reference, 1 ha for the willow SRC reference, and 1 ha for the agroforestry system consisting of 55\% grassland and $45 \%$ willow SRC. A 5-km distance from farm to field was assumed. Energy inputs for establishment of the cropping systems and site restoration from willow SRC back to arable land composed $16.6 \%$ of the energy balance and assumed a lifespan of the cropping systems of 18 years (6 rotation cycles).

For biogas conversion to energy in WCD and IFBB press fluid digestion scenarios, a combined heat and power process with 30\% electric and 50\% thermal conversion efficiency was assumed. For solid fuel combustion $85 \%$ thermal conversion efficiency was assumed.

\subsection{Statistics}

Statistical tests were conducted using the software R [41]. One-factor analysis of variance (ANOVA) was performed to test the effect of biomass type and conversion system on the biomass- and area-specific methane yield, as well as on the HHV, dry matter, ash and mineral contents in solid fuels (hay and IFBB press cake). Assumptions of the ANOVA were tested using the Shapiro-Wilk test for normality of the residuals and the Levene's test for homogeneity of variances. A difference was considered statistically significant if the $p$ value for the ANOVA was below 0.05. Due to the gap between the projects, input- and output-parameters of the energy balance could not be based on field measurements for the first cut in 2015. Therefore, the following regressions were performed to calculate the net energy yield of the first cut of 2015 using the data from all cuts in 2015, 2016 and 2017:

$$
\begin{aligned}
& \text { NetEnergyYield }{ }_{W C D g r a s s}[\text { MWh ha } \\
& \\
& \text { with an adjusted } R^{2} \text { of } 0.95
\end{aligned}
$$$$
\text { NetEnergyYield } \left.\text { IFBBgrass }_{\text {MWh ha }}{ }^{-1}\right]=1.999 \times \text { DMYield }_{\text {IFBBgrass }}\left[\text { MG DM ha }{ }^{-1}\right]-0.3846
$$$$
\text { with an adjusted } R^{2} \text { of } 0.86 \text {, }
$$ 
with an adjusted $R^{2}$ of 0.99 ,

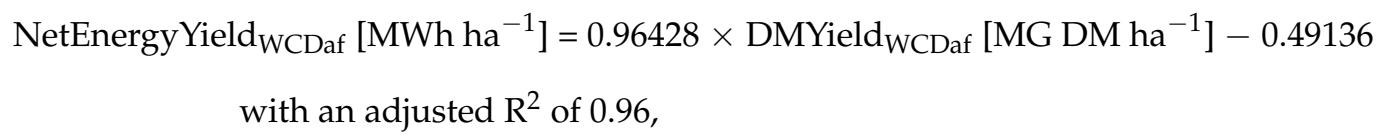
NetEnergyYield IFBBaf $\left[\right.$ MWh ha $\left.{ }^{-1}\right]=0.91168 \times$ DMYield $_{\text {IFBBaf }}\left[\mathrm{MG} \mathrm{DM} \mathrm{ha}^{-1}\right]-0.04504$
with an adjusted $R^{2}$ of 0.82 ,

NetEnergyYield $\mathrm{CHaf}_{\mathrm{CHh}}\left[\mathrm{MWh}^{-1}\right]=1.32039 \times \mathrm{DMYield}_{\mathrm{CHaf}}\left[\mathrm{MG} \mathrm{DM} \mathrm{ha}{ }^{-1}\right]-0.30430$
with an adjusted $\mathrm{R}^{2}$ of 0.99 , where DMYield is the dry matter yield, the subscript grass indi-
cates the reference grassland stand, and the subscript af indicates the agroforestry systems.

\section{Results and Discussion}

\subsection{Methane Yields}

Biomass- and area-specific methane yields of the IFBB press fluids did not show any significant differences between the grassland types (Table 3 ). The biomass-specific methane yields showed a mean value of $285.4 \mathrm{~L}_{\mathrm{N}} \mathrm{CH}_{4} \mathrm{~kg}^{-1} \mathrm{VS}$ for $\mathrm{CG}$ and $302.4 \mathrm{~L}_{\mathrm{N}} \mathrm{CH}_{4} \mathrm{~kg}^{-1} \mathrm{VS}$ for DG. In comparison to the data of Ehret et al. [23] from the same experimental site in the first rotation, the biomass- and area-specific methane yields were lower. This can be attributed to lower quality of the biomass and subsequently lower quality of the press fluid. Studies have shown that the higher the DM and fiber content in the biomass, the lower the methane yield achievable with press fluid digestion [42]. The area-specific methane yield is dependent on the biomass-specific methane yield and on the yield of biomass, which was considerably lower in the second rotation than in the first rotation [25]. Thus, both effects caused a lower area-specific methane yield in the second rotation [23].

Table 3. Arithmetic mean \pm standard error of mean of volatile solid content of press fluids and silages, biomass-specific methane yield and area-specific methane yield for press fluid from integrated generation of solid fuel and biogas from biomass (IFBB) and whole crop digestion of silage (WCD) of two different alley cropped grassland mixtures and $p$-value of the ANOVA testing the effect of biomass type on biomass and area specific methane yields.

\begin{tabular}{ccccc}
\hline Conversion System & Volatile Solid Content/Methane Yield & Clover Grass (CG) & Diversity (DG) & $p$-Value \\
\hline \multirow{2}{*}{ IFBB } & Volatile solid content of press fluids $(\%$ of FM) & $0.46 \pm 0.1$ & $0.62 \pm 0.2$ & - \\
& Biomass specific methane yield $\left(\mathrm{L}_{\mathrm{N}} \mathrm{kg}^{-1} \mathrm{VS}\right)$ & $285.4 \pm 18.7$ & $302.4 \pm 21.2$ & 0.565 \\
& Area specific methane yield $\left(\mathrm{m}^{3} \mathrm{ha}^{-1}\right)$ & $125.0 \pm 41.7$ & $181.1 \pm 66.6$ & 0.495 \\
\hline \multirow{2}{*}{ WCD } & Volatile solid content of silages $(\%$ of FM) & $26.37 \pm 3.4$ & $27.55 \pm 2.9$ & - \\
& Biomass specific methane yield $\left(\mathrm{L}_{\mathrm{N}} \mathrm{kg}^{-1} \mathrm{VS}\right)$ & $231.5 \pm 11.5$ & $230.9 \pm 11.4$ & 0.971 \\
& Area specific methane yield $\left(\mathrm{m}^{3} \mathrm{ha}^{-1}\right)$ & $343.6 \pm 83.4$ & $280.3 \pm 101.4$ & 0.634 \\
\hline
\end{tabular}

No significant differences between the grassland types were observed for biomassspecific and area-specific methane yields of WCD (Table 3). The assumption of normal distribution of residuals was violated for both the area- and the biomass-specific methane yield. We used ANOVA for these cases anyway, as several authors have pointed out that ANOVA is quite robust to violations of this assumption [43]. This result is contrary to the first rotation, in which the difference in yields between DG and CG were higher [23]. This might be attributed to the time passed after seeding the grassland (2011) and natural processes of convergence of the species compositions of both grassland types.

The biomass-specific methane yield was significantly higher for the IFBB press fluids than for the WCD ( $p$-value of the ANOVA equal to 0.0002), even though the press fluids were produced from grassland cut twice a year and the silage for the WCD from grass cut three times a year. The grassland silage for press fluid production was more mature and thus had a higher degree of lignification. This result is backed up by a large number of 
studies showing that the IFBB system leads to a concentration of easily digestible nutrients in the press fluids and thus a higher biomass-specific biogas yield $[28,44,45]$.

The average area-specific methane yield was higher for the WCD than the IFBB system, but this difference was not statistically significant according to the pre-set type I error rate of $5 \%$ ( $p$-value $=0.0804)$. This is due to the very high standard errors of the means that were observed, especially for the area-specific methane yields of the WCD system. The assumption of normal distribution of residuals was violated. Former research [42] on area-specific methane yields found yields for WCD were higher compared to IFBB. This is a logical conclusion of the fact that approximately $80 \%$ of the organic DM of the biomass are transferred into the press cake within the IFBB system (data not shown) [29,31,45]; thus, only part of the biomass is available for biogas production.

\subsection{Fuel Quality}

The HHV of the IFBB press cakes increased by $4.56 \%$ and $2.92 \%$ for CG and DG, respectively, compared to the HHV of hay (Table 4). ANOVA confirmed significant differences between the conversion pathways IFBB and combustion of hay (Table 5). Additionally, press cakes had lower ash and mineral concentrations as the consequence of the washing and mechanical dehydration step of the IFBB system and are consistent with research done in former studies on a broad range of biomass types, from urban green cuttings and leaves to semi-natural grassland biomass $[31,42,44,46]$.

Table 4. Fuel characteristics of hay, integrated generation of solid fuel and biogas from biomass (IFBB) press cakes and willow short rotation coppice (SRC) woodchips produced from two alley-cropped grassland mixtures (clover-grass (CG) and a diverse mixture (DG)). $\mathrm{HHV}=$ higher-heating value, $\mathrm{DM}=$ dry matter.

\begin{tabular}{|c|c|c|c|c|c|c|c|c|}
\hline Solid Fuel & Grassland Type & HHV & DM & Ash & $\mathrm{Cl}$ & $\mathbf{K}$ & $\mathbf{N}$ & $\mathrm{S}$ \\
\hline & & $\mathrm{MJ} \mathrm{kg}{ }^{-1} \mathrm{DM}$ & $\%$ & & & $\% \mathrm{DM}$ & & \\
\hline \multirow[t]{2}{*}{ Hay $^{a}$} & CG & $17.98 \pm 0.20$ & $91.05 \pm 0.33$ & $12.01 \pm 1.22$ & $1.19 \pm 0.23$ & $2.87 \pm 0.12$ & $1.67 \pm 0.24$ & $0.24 \pm 0.04$ \\
\hline & DG & $18.46 \pm 0.16$ & $89.71 \pm 0.54$ & $11.31 \pm 0.96$ & $0.99 \pm 0.12$ & $2.52 \pm 0.06$ & $2.00 \pm 0.20$ & $0.24 \pm 0.03$ \\
\hline IFBB & CG & $18.80 \pm 0.16$ & $93.35 \pm 0.58$ & $5.61 \pm 0.45$ & $0.11 \pm 0.02$ & $0.49 \pm 0.03$ & $1.30 \pm 0.23$ & $0.11 \pm 0.02$ \\
\hline press cake $^{a}$ & DG & $19.00 \pm 0.09$ & $92.67 \pm 0.39$ & $5.83 \pm 0.54$ & $0.12 \pm 0.02$ & $0.48 \pm 0.01$ & $1.42 \pm 0.15$ & $0.12 \pm 0.02$ \\
\hline $\begin{array}{l}\text { Willow SRC } \\
\text { woodchips }\end{array}$ & & 19.70 & & 2.0 & 0.004 & 0.26 & 0.54 & 0.05 \\
\hline Guiding value $^{c}$ & & & & & $<0.1$ & & $<0.6$ & $<0.1$ \\
\hline
\end{tabular}

${ }^{a}$ Mean values \pm standard error of mean are shown over the three experimental years $(2015,2016,2017) ;{ }^{b}$ Fuel characteristics of willow SRC are based on [39]; ${ }^{c}$ Guiding values for unproblematic combustion based on [47].

Table 5. Results of analysis of variance ( $p$-values) for the effect of conversion pathway (combustion of hay $(\mathrm{CH})$ and integrated generation of solid fuel and biogas from biomass (IFBB)) and for the effect of grassland type (clover-grass (CG) and diverse mixture (DG)) on higher heating value (HHV), dry matter (DM), ash and mineral concentration in the hay and IFBB press cake.

\begin{tabular}{cccccccc}
\hline & HHV & DM & Ash & Cl & K & N & S \\
\hline $\begin{array}{c}\text { Conversion pathway } \\
\text { (CH, IFBB) }\end{array}$ & $<0.001$ & $<0.001$ & $<0.001$ & $<0.001$ & $<0.001$ & 0.0385 & $<0.001$ \\
\hline $\begin{array}{c}\text { Grassland type } \\
(\text { CG, DG) }\end{array}$ & 0.14 & 0.204 & 0.868 & 0.704 & 0.729 & 0.278 & 0.959 \\
\hline
\end{tabular}

There were only minor differences between DG and CG solid fuels in terms of ash, mineral and $\mathrm{N}$ content. ANOVA confirmed that differences due to grassland types are not significant (Table 5). Willow SRC woodchips had comparably lower levels of ash and mineral contents and therefore a higher HHV. These findings support the methane yield results, where also no differences were detected between the two biomass types. Astonishingly, DG has even higher $\mathrm{N}$ concentrations than CG. The complete sward composition was not determined, so the reason for the similarity between the two biomass types could not be 
verified. The values for $\mathrm{Cl}$ and $\mathrm{S}$ in the hay are higher than the recommended guiding values for unproblematic combustion [48]. Thus, combusting the hay without further treatment would cause problems such as corrosion and unwanted emissions. Likewise, the high values for $\mathrm{K}$ would most likely lead to a low ash melting temperature and therefore ash slagging. Therefore, this conversion pathway for grassland biomass is not feasible in practice.

The IFBB press cakes had lower concentrations of $\mathrm{K}, \mathrm{S}$ and $\mathrm{Cl}$, similar to results shown in other studies $[29,44,46]$. The values of $\mathrm{S}$ and $\mathrm{Cl}$ were only slightly exceeding the guiding values proposed by Obernberger et al. [47]. The total concentration of ash was reduced from $12.02 \%$ to $5.61 \%$ DM for the CG biomass and from $11.31 \%$ to $5.83 \%$ DM for the DG. The reduction of ash led to an increase in the HHV. An increase in temperature [48] or the amount of water used during hydrothermal conditioning [49] increases the efficiency of mineral and ash removal; therefore, it can be assumed that with small adaptations to the hydrothermal conditioning step, the fuel quality could be further optimized and $\mathrm{Cl}$ and $\mathrm{S}$ reduced below the guiding values.

\subsection{Net Energy Balance}

For the grassland reference system, the net energy balance was highest for $\mathrm{CH}$, second highest for IFBB, and lowest for WCD, except for in 2015, when WCD had higher values than IFBB due to substantially higher biomass yields in the WCD system in that year (Figure 3).

(a)

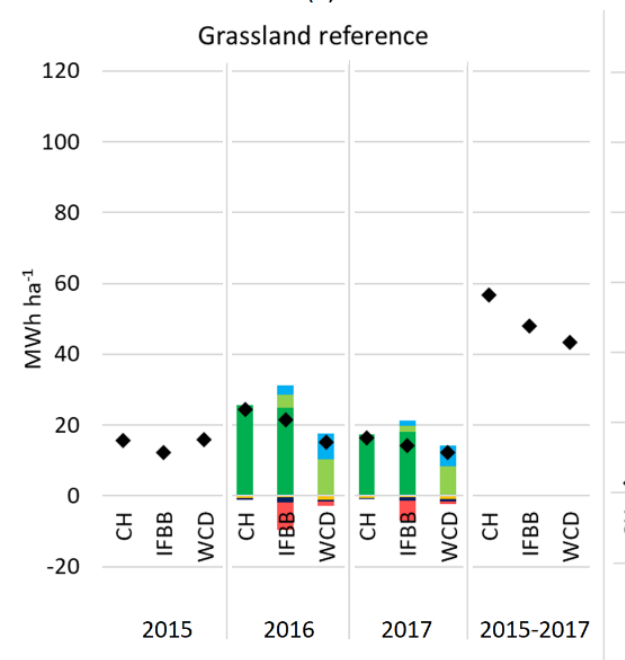

(b)

CG - Willow SRC in agroforestry system (c)

DG - Willow SRC in agroforestry system (d)

Willow SRC reference

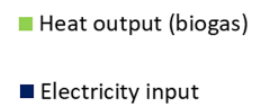

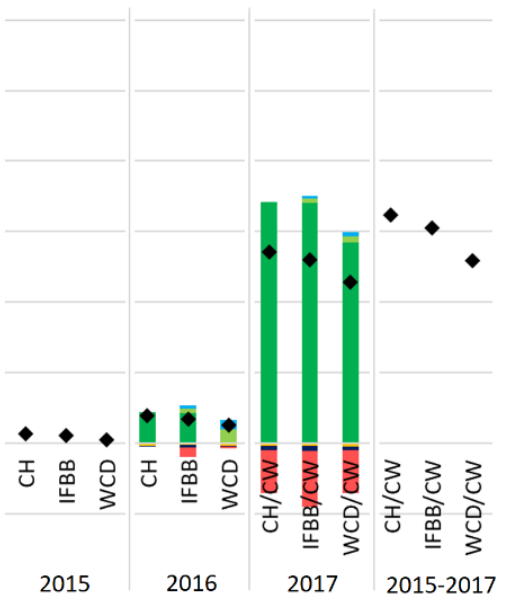

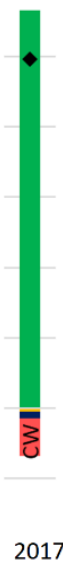

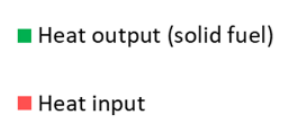

Heat input

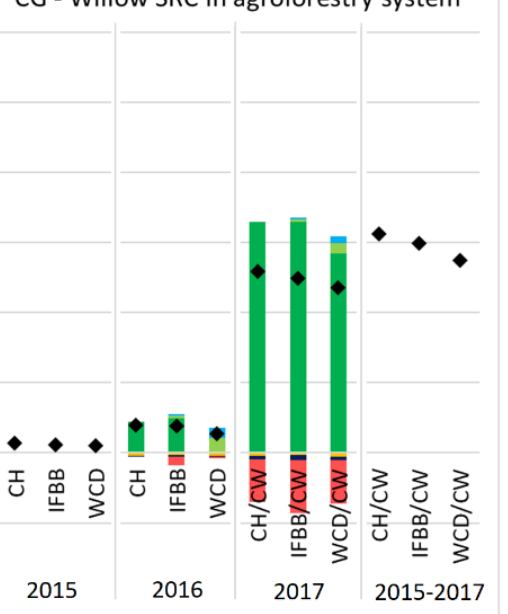

\author{
Electricity output (biogas) \\ Diesel input
}

- Net energy output

Figure 3. Energy input, output, and net energy yields of (b) clover grass (CG) and willow short rotation coppice (SRC) in agroforestry system and (c) diverse grassland mixture (DG) and willow short rotation coppice (SRC) in agroforestry system compared to grassland reference stand (a) and willow short rotation coppice (SRC) reference stand (d) in the second rotation after establishment. Four conversion technologies were applied: combustion of hay $(\mathrm{CH})$, integrated generation of solid fuels and biogas from biomass (IFBB), whole crop digestion (WCD) and combustion of willow woodchips (CW).

The lowest net energy value for the grassland system was achieved by the WCD system in 2017 with $12.2 \mathrm{MWh} \mathrm{ha}^{-1}$; the highest value was achieved by the $\mathrm{CH}$ system in 2016 with $24.5 \mathrm{MWh} \mathrm{ha}^{-1}$. The triennial net energy yield was $56.72 \mathrm{MWh} \mathrm{ha}^{-1}$ for $\mathrm{CH}$, 
47.97 MWh ha ${ }^{-1}$ for IFBB and 43.37 MWh ha ${ }^{-1}$ for WCD. Nevertheless, as mentioned before, the $\mathrm{CH}$ system is not feasible in practice due to high maintenance effort required in hay combustion. Moreover, it only produces lower quality energy in the form of heat (less exergy compared to electricity), whereas the IFBB system produces heat from solid fuel and biogas as well as a small amount of electricity. Within the IFBB system, about $82 \%$ of the energy was in the form of heat from solid fuel, $11 \%$ as heat from biogas combustion and $7 \%$ as electricity from biogas combustion. For WCD, heat from biogas $(59 \%)$ and electricity from biogas (41\%) were more evenly distributed. The net energy input was highest for the IFBB system, mainly due to the energy-intensive drying of the press cakes from about $50 \%$ DM to $85 \%$ DM. Drying is necessary to make the press cake storable and transportable. Field operations only contribute a small amount to the total inputs.

For the agroforestry system with CG, the yields in the years without tree harvest were naturally lower than in the reference grassland system, as part of the area is dedicated to trees and there is no yield in those years (Figure 3). However, on a lower level, the net energy balance followed the same order for the conversion systems, with the highest yields for CH and IFBB and lower yields for WCD. Higher yields were achieved in 2017, which included the yield of the tree harvest. The sum of the three years revealed net energy gains of $62.60 \mathrm{MWh} \mathrm{ha}^{-1}$ for $\mathrm{CH} / \mathrm{CW}$, 59.75 MWh ha ${ }^{-1}$ for IFBB/CW, and 54.87 MWh ha ${ }^{-1}$ for $\mathrm{WCD} / \mathrm{CW}$. Thus, the net energy yields were in all cases slightly higher for the agroforestry system than for the reference grassland system—other than in the first rotation [23]. This was mainly caused by higher willow SRC biomass yields in the agroforestry system in comparison to the first rotation. Grassland biomass yields in agroforestry system were lower than in the grassland reference system. This was partly due to the small width of the grassland strips, allowing much of the grassland to be shaded by the willow trees [50]. Another reason was longer periods of drought during the 2nd rotation, which enhanced the competition for water between trees and grassland.

The results for the agroforestry system with DG and CG were very similar (Figure 3). Again, the $\mathrm{CH}$ system resulted in the highest net energy yields, IFBB in the second highest, and WCD in the lowest. The sums for the three years were 64.67, 60.96 and 51.69 $\mathrm{MWh}^{-1}$ for $\mathrm{CH} / \mathrm{CW}$, IFBB/CW and WCD/CW, respectively. Comparing the two agroforestry systems, $\mathrm{CH}$ and IFBB had higher net gains in the diversity agroforestry system, whereas the WCD system had better results in the CG system than in the DG mixture. This can be explained by the higher area-specific methane yields for WCD in the CG agroforestry system and the higher area-specific methane yield in the DG system for IFBB (Table 3).

The pure willow SRC reference had the highest net energy gains, with 99.39 $\mathrm{MWh} \mathrm{ha}^{-1}$ in 3 years (Figure 3). This is due to the high biomass yield and the comparatively low annual inputs necessary in a SRC system, as field operations are limited. In the first rotation of the experiment, the combustion of willow SRC wood chips achieved a net energy yield of only $23 \mathrm{MWh} \mathrm{Ma}^{-1}$ due to low growth rates in the first years after establishment. As growth rate of willow SRC is known to increase after the first rotation [51-54], the net energy balance logically also increased in the second rotation.

\section{Conclusions}

The investigated agroforestry system had lower energy yield compared to the willow SRC reference. Nevertheless, the net energy balances of the agroforestry system were positive. Therefore, it is a suitable renewable energy alternative for substituting fossil energy and contributing to the mitigation of the climate crisis. On the other hand, the comparison of energy yields only does not reflect the full range of environmental and economic implications of both systems. Therefore, they shall be seen in a broader context. For example, considering the impacts on soil quality, carbon stocks, nutrient recycling and land use change.

Within the agroforestry system, there were pronounced differences among the conversion methods, with $\mathrm{CH}$ and IFBB showing higher net energy yields than WCD. As well here the different conversion systems shall be viewed beyond energy yields only. IFBB 
and in particular WCD system compared to $\mathrm{CH}$ allows to produce renewable electricity in addition to heat. Moreover, the nutrients remaining in the biogas digestate can be recovered and thus the renewable energy production can be coupled with other crop and animal production systems. Even when $\mathrm{CH}$ had the highest energy yields of all grassland biomass conversion systems, in practice the combustion of hay is not feasible due to increased emissions and ash slagging. IFBB treatment resulted in lower contents of $\mathrm{Cl}, \mathrm{K}$, and $\mathrm{S}$ and thus significantly improved the quality of the grassland biomass fuel.

The different grassland types within the agroforestry system did not lead to large differences in fuel quality or energy balance. However, to verify the similarity of the two assessed grassland biomass types, further determination of complete sward composition within the next rotations is needed. The net energy yields of all systems were higher in the second rotation of the willow SRC, but the gains were higher for the willow SRC reference and agroforestry systems compared to the grassland reference system.

Author Contributions: Conceptualization, R.G. and M.W.; Data curation, F.H.; Formal analysis, F.H. and I.D.; Funding acquisition, R.G.; Methodology, R.G. and M.W.; Project administration, R.G.; Supervision, I.D., R.G. and M.W.; Writing—original draft, F.H.; Writing—review \& editing, I.D., R.G. and M.W. All authors have read and agreed to the published version of the manuscript.

Funding: This work was funded by the German Ministry of Education and Research (BMBF) as a part of the research project "Sustainable intensification of agriculture through agroforestry" (SIGNAL, grant number 031B0510B) within the Framework Program "Soil as a sustainable resource for the bioeconomy" (BONARES).

Institutional Review Board Statement: Not applicable.

Informed Consent Statement: Not applicable.

Acknowledgments: The authors thank Wolfgang Funke, Andrea Gerke and Sarah Malec for their technical support in experiments of biomass conversion, data curation and analyses.

Conflicts of Interest: The authors declare no conflict of interest. The funders had no role in the design of the study, in the collection, analyses, or interpretation of data, in the writing of the manuscript, and in the decision to publish the results.

\section{References}

1. United Nations. United Nations Framework Convention on Climate Change: UNFCCC. Available online: https://unfccc.int/ sites / default/files/convention_text_with_annexes_english_for_posting.pdf (accessed on 15 May 2019).

2. UNFCCC. Adoption of the Paris Agreement-Paris Agreement Text English. Available online: https://unfccc.int/sites/default/ files/english_paris_agreement.pdf (accessed on 12 July 2019).

3. Elzen, M.D.; Fekete, H.; Fransen, T.; Höhne, N.; Meinshausen, M.; Riahi, K.; Rogelj, J.; Schaeffer, R.; Sha, F.; Winkler, H. Paris Agreement climate proposals need a boost to keep warming well below $2{ }^{\circ} \mathrm{C}$. Nature 2016, 534, 631-639. [CrossRef]

4. Creutzig, F.; Ravindranath, N.H.; Berndes, G.; Bolwig, S.; Bright, R.; Cherubini, F.; Chum, H.; Corbera, E.; Delucchi, M.; Faaij, A.; et al. Bioenergy and climate change mitigation: An assessment. GCB Bioenergy 2015, 7, 916-944. [CrossRef]

5. Immerzeel, D.J.; Verweij, P.A.; van der Hilst, F.; Faaij, A.P.C. Biodiversity impacts of bioenergy crop production: A state-of-the-art review. GCB Bioenergy 2014, 6, 183-209. [CrossRef]

6. Pugesgaard, S.; Schelde, K.; Larsen, S.U.; Laerke, P.E.; Jørgensen, U. Comparing annual and perennial crops for bioenergy production-Influence on nitrate leaching and energy balance. GCB Bioenergy 2015, 7, 1136-1149. [CrossRef]

7. Gregg, J.S.; Izaurralde, R.C. Effect of crop residue harvest on long-term crop yield, soil erosion and nutrient balance: Trade-offs for a sustainable bioenergy feedstock. Biofuels 2010, 1, 69-83. [CrossRef]

8. Rathmann, R.; Szklo, A.; Schaeffer, R. Land use competition for production of food and liquid biofuels: An analysis of the arguments in the current debate. Renew. Energy 2010, 35, 14-22. [CrossRef]

9. Buchholz, T.; Luzadis, V.A.; Volk, T.A. Sustainability criteria for bioenergy systems: Results from an expert survey. J. Clean. Prod. 2009, 17, S86-S98. [CrossRef]

10. Mitchell, C.; Stevens, E.; Watters, M. Short-rotation forestry-operations, productivity and costs based on experience gained in the UK. For. Ecol. Manag. 1999, 121, 123-136. [CrossRef]

11. Di Nasso, O.N.N.; Guidi, W.; Ragaglini, G.; Tozzini, C.; Bonari, E. Biomass production and energy balance of a 12-year-old short-rotation coppice poplar stand under different cutting cycles. GCB Bioenergy 2010, 2, 89-97. [CrossRef]

12. Huber, J.A.; May, K.; Siegl, T.; Schmid, H.; Gerl, G.; Hülsbergen, K.-J. Yield potential of tree species in organic and conventional short-rotation agroforestry systems in southern Germany. Bioenergy Res. 2016, 9, 955-968. [CrossRef] 
13. Karp, A.; Shield, I. Bioenergy from plants and the sustainable yield challenge. New Phytol. 2008, 179, 15-32. [CrossRef] [PubMed]

14. Börjesson, P.; Tufvesson, L.M. Agricultural crop-based biofuels-resource efficiency and environmental performance including direct land use changes. J. Clean. Prod. 2011, 19, 108-120. [CrossRef]

15. Hennig, C.; Gawor, M. Bioenergy production and use: Comparative analysis of the economic and environmental effects. Energy Convers. Manag. 2012, 63, 130-137. [CrossRef]

16. Karp, A.; Richter, G.M. Meeting the challenge of food and energy security. J. Exp. Bot. 2011, 62, 3263-3271. [CrossRef] [PubMed]

17. Dauber, J.; Jones, M.B.; Stout, J.C. The impact of biomass crop cultivation on temperate biodiversity. GCB Bioenergy 2010, 2, 289-309. [CrossRef]

18. Costanzo, A.; Bàrberi, P. Functional agrobiodiversity and agroecosystem services in sustainable wheat production. A review. Agron. Sustain. Dev. 2014, 34, 327-348. [CrossRef]

19. Jose, S. Agroforestry for ecosystem services and environmental benefits: An overview. Agrofor. Syst. 2009, 76, 1-10. [CrossRef]

20. Beuschel, R.; Piepho, H.-P.; Joergensen, R.G.; Wachendorf, C. Impact of willow-based grassland alley cropping in relation to its plant species diversity on soil ecology of former arable land. Appl. Soil Ecol. 2020, 147, 103373. [CrossRef]

21. Long, A.J.; Nair, P.R. Trees outside forests: Agro-, community, and urban forestry. New For. 1999, 17, 145-174. [CrossRef]

22. Quinkenstein, A.; Wöllecke, J.; Böhm, C.; Grünewald, H.; Freese, D.; Schneider, B.U.; Hüttl, R.F. Ecological benefits of the alley cropping agroforestry system in sensitive regions of Europe. Environ. Sci. Policy 2009, 12, 1112-1121. [CrossRef]

23. Ehret, M.; Bühle, L.; Graß, R.; Lamersdorf, N.; Wachendorf, M. Bioenergy provision by an alley cropping system of grassland and shrub willow hybrids: Biomass, fuel characteristics and net energy yields. Agrofor. Syst. 2015, 89, 365-381. [CrossRef]

24. Ehret, M.; Graß, R.; Wachendorf, M. Productivity at the tree-crop interface of a young willow-grassland alley cropping system. Agrofor. Syst. 2018, 92, 71-83. [CrossRef]

25. Graß, R.; Malec, S.S.; Wachendorf, M. Biomass performance and competition effects in an established temperate agroforestry system of willow and grassland-Results of the 2nd rotation. Agronomy 2020, 10, 1819. [CrossRef]

26. Rowe, R.L.; Hanley, M.E.; Goulson, D.; Clarke, D.J.; Doncaster, C.P.; Taylor, G. Potential benefits of commercial willow Short Rotation Coppice (SRC) for farm-scale plant and invertebrate communities in the agri-environment. Biomass Bioenergy 2011, 35, 325-336. [CrossRef]

27. McKendry, P. Energy production from biomass (part 1): Overview of biomass. Bioresour. Technol. 2002, 83, 37-46. [CrossRef]

28. Richter, F.; Graß, R.; Fricke, T.; Zerr, W.; Wachendorf, M. Utilization of semi-natural grassland through integrated generation of solid fuel and biogas from biomass. II. Effects of hydrothermal conditioning and mechanical dehydration on anaerobic digestion of press fluids. Grass Forage Sci. 2009, 64, 354-363. [CrossRef]

29. Wachendorf, M.; Richter, F.; Fricke, T.; Graß, R.; Neff, R. Utilization of semi-natural grassland through integrated generation of solid fuel and biogas from biomass. I. Effects of hydrothermal conditioning and mechanical dehydration on mass flows of organic and mineral plant compounds, and nutrient balances. Grass Forage Sci. 2009, 64, 132-143. [CrossRef]

30. Bühle, L.; Dürl, G.; Hensgen, F.; Urban, A.; Wachendorf, M. Effects of hydrothermal conditioning and mechanical dewatering on ash melting behaviour of solid fuel produced from European semi-natural grasslands. Fuel 2014, 118, 123-129. [CrossRef]

31. Hensgen, F.; Bühle, L.; Donnison, I.; Frasier, M.; Vale, J.; Corton, J.; Heinsoo, K.; Melts, I.; Wachendorf, M. Mineral concentrations in solid fuels from European semi-natural grasslands after hydrothermal conditioning and subsequent mechanical dehydration. Bioresour. Technol. 2012, 118, 332-342. [CrossRef]

32. Rao, M.R.; Coe, R.D. Measuring crop yields in on-farm agroforestry studies. Agrofor. Syst. 1991, 15, 275-289. [CrossRef]

33. World Reference Base for Soil Resources 2014: International Soil Classification System for Naming Soils and Creating Legends for Soil Maps; FAO: Rome, Italy, 2014.

34. Hartmann, L.; Richter, F.; Busch, G.; Ehret, M.; Jansen, M.; Lamersdorf, N. Establishment of short rotation coppices in the South of Lower Saxony and in Central Thuringia in the context of the BEST-research framework-Site characteristics and initial biomass production. Forstarchiv 2014, 85, 134-150. [CrossRef]

35. KTBKuratorium für Technik und Bauwesen in der Landwirtschaft e.V. KTBL-Dieselbedarf. Available online: https:/ / daten.ktbl. de/dieselbedarf/main.html (accessed on 10 July 2019).

36. Zerr, W. Versuchsanlage zur energetischen Beurteilung von Substraten und Kofermentaten für Biogasanlagen. UWSF-Z Umweltchem Ökotox 2006, 18, 219-227. [CrossRef]

37. Verein deutscher Ingenieure. Vergärung Organischer Stoffe [Fermentation of Organic Materials]; Beuth: Berlin, Germany, 2006.

38. Weissbach, F.; Kuhla, S. Substance losses in determining the dry matter content of silage and green fodder: Arising errors and possibilities of correction. Uebersichten Tierernaehrung 1995, 23, 189-214.

39. Kaltschmitt, M.; Hartmann, H.; Hofbauer, H. Energie aus Biomasse, 3rd ed.; Springer: Berlin/Heidelberg, Germany, 2016.

40. Friedl, A.; Padouvas, E.; Rotter, H.; Varmuza, K. Prediction of heating values of biomass fuel from elemental composition. Anal. Chim. Acta 2005, 544, 191-198. [CrossRef]

41. R Development Core Team. $R-A$ Language and Environment for Statistical Computing; R Foundation for Statistical Computing: Vienna, Austria, 2009.

42. Richter, F.; Fricke, T.; Wachendorf, M. Influence of sward maturity and pre-conditioning temperature on the energy production from grass silage through the integrated generation of solid fuel and biogas from biomass (IFBB): 2. Properties of energy carriers and energy yield. Bioresour. Technol. 2011, 102, 4866-4875. [CrossRef] [PubMed]

43. Schmider, E.; Ziegler, M.; Danay, E.; Beyer, L.; Bühner, M. Is it really robust? Methodology 2010, 6, 147-151. [CrossRef] 
44. Nitsche, M.; Hensgen, F.; Wachendorf, M. Using grass cuttings from sports fields for anaerobic digestion and combustion. Energies 2017, 10, 388. [CrossRef]

45. Hensgen, F.; Bühle, L.; Donnison, I.; Heinsoo, K.; Wachendorf, M. Energetic conversion of European semi-natural grassland silages through the integrated generation of solid fuel and biogas from biomass: Energy yields and the fate of organic compounds. Bioresour. Technol. 2014, 154, 192-200. [CrossRef]

46. Nurmatov, N.; Leon Gomez, D.; Hensgen, F.; Bühle, L.; Wachendorf, M. High-quality solid fuel production from leaf litter of urban street trees. Sustainability 2016, 8, 1249. [CrossRef]

47. Obernberger, I.; Brunner, T.; Barnthaler, G. Chemical properties of solid biofuels—Significance and impact. Biomass Bioenergy 2006, 30, 973-982. [CrossRef]

48. Richter, F.; Fricke, T.; Wachendorf, M. Influence of sward maturity and pre-conditioning temperature on the energy production from grass silage through the integrated generation of solid fuel and biogas from biomass (IFBB): 1 . The fate of mineral compounds. Bioresour. Technol. 2011, 102, 4855-4865. [CrossRef] [PubMed]

49. Hensgen, F; Wachendorf, M. Aqueous leaching prior to dewatering improves the quality of solid fuels from grasslands. Energies 2018, 11, 846. [CrossRef]

50. Ehret, M.; Graß, R.; Wachendorf, M. The effect of shade and shade material on white clover/perennial ryegrass mixtures for temperate agroforestry systems. Agrofor. Syst. 2015, 89, 557-570. [CrossRef]

51. Aylott, M.J.; Casella, E.; Tubby, I.; Street, N.R.; Smith, P.; Taylor, G. Yield and spatial supply of bioenergy poplar and willow short-rotation coppice in the UK. New Phytol. 2008, 178, 358-370. [CrossRef]

52. Dimitriou, I.; Mola-Yudego, B.; Aronsson, P. Impact of willow short rotation coppice on water quality. Bioenergy Res. 2012, 5, 537-545. [CrossRef]

53. Stork, M.; Schulte, A.; Murach, D. Large-scale fuelwood production on agricultural fields in mesoscale river catchments-GISbased determination of potentials in the Dahme river catchment (Brandenburg, NE Germany). Biomass Bioenergy 2014, 64, 42-49. [CrossRef]

54. Wilkinson, J.; Evans, E.; Bilsborrow, P.; Wright, C.; Hewison, W.; Pilbeam, D. Yield of willow cultivars at different planting densities in a commercial short rotation coppice in the north of England. Biomass Bioenergy 2007, 31, 469-474. [CrossRef] 